\title{
Erratum
}

\section{Initiating Participatory Action Research with Older Adults: Lessons Learned through Reflexivity-ERRATUM}

Carri Hand, Debbie Laliberte Rudman, Colleen McGrath, Catherine Donnelly, and Michele Sands

https:/ / doi.org/10.1017/S0714980819000072. Published by Cambridge University Press, 8 March 2019

There was a misspelling in the title of this research note in the original version published online. The error has been corrected.

We regret the error.

\section{Reference}

Hand, C., Laliberte Rudman, D., McGrath, C., Donnelly, C., \& Sands, M. (2019). Initiating participatory action research with older adults: Lessons learned through reflexivity. Canadian Journal on Aging/La Revue canadienne du vieillissement, 38. https://doi.org/10.1017/S0714980819000072. 